


\title{
There's No Passion; I Need Passion: Why Some Brands Excite Consumers So Much
}

\author{
Andrea Hemetsberger
}

\author{
KEYWORDS \\ Passion, Brand Experience, \\ Self-Transformation, Personality \\ THE AUTHOR \\ Andrea Hemetsberger, \\ Professor of Branding, \\ University of Innsbruck, Austria, \\ andrea.hemetsberger@uibk.ac.at
}

When brightly polished Golf GTIs hit the road with their engines roaring and wheels a-squealing: That's how you know it's time for up to 200,000 passionate car enthusiasts to make their yearly pilgrimage to a four-day spectacle - the GTI Brandfest. Harley Davidson fans, Trekkies, Abercrombie \& Fitch groupies, shoe fetishists and collectors of glass figurines serve as additional examples of the ubiquitous nature of this phenomenon. Consumers, just like Rod Stewart sang in his famous song, are looking for passion - which they find and nourish in certain brands. Passion commonly accompanies very intense relationships between consumers and objects or activities. As in interpersonal relationships, consumer passion can be defined as an intense feeling of attraction toward and desire for an object. Passion is linked to strong feelings like love, feelings of spiritual or religious excitement, and adoration, and often implies religious fervor and zeal.

What makes a brand a passion brand /// Companies commonly love to think of their brands as offers that excite their consumers and evoke strong emotions. However, not all brands have the potential to develop into such meaningful objects and relationship partners. They need to serve certain psychological and symbolic functions in order to qualify as passion brands. One common feature of these is the fact that they help consumers define and express a strong personality, serving their psychological well-being and/or their social status. Passion brands send strong social signals. Therefore, consumers engage in collective forms of passion, which is commonly addressed as consumer fandom. Researchers, for 


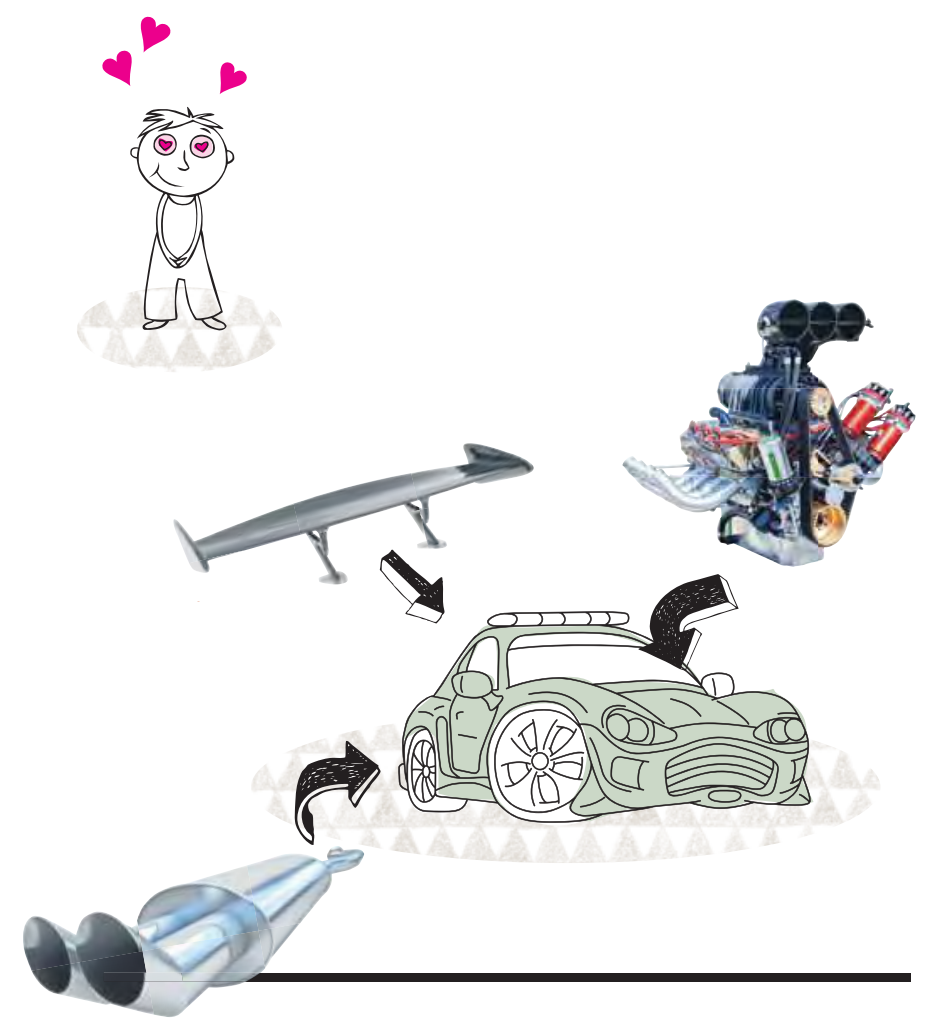

instance, report of Star Trek fans who describe their bond with this TV series as "devotion." They dress like their Star Trek heroes, they meet with other like-minded fans to share their passion, and they produce their own Star Trek episodes. Other studies describe Harley Davidson fans' strong potential for building subcultures of consumption and developing their own rituals and language. Loyal Mac users have even been portrayed as acting like religious zealots. Some brands, however, also become very private objects of devotion, bringing about feelings of closeness and intimacy. Can you think of any? How about in your closet, your bathroom, your garage, or locker room? It is not uncommon to hear about a person's passion for lingerie or a collector's passion for certain kinds of objects or artwork.
Who is passionate? /// Studies have found that consumers who show their passion in public have distinct personalities. Depending on the specific attributes of the brand, very open-minded consumers who like to be intellectually stimulated appreciate brands with mind-boggling qualities and are eager to know everything about the brand. As their brand knowledge increases, their passionate feelings toward the brand increase as well. Extroverted consumer personalities exhibit strong feelings of passion toward the brand instead of constantly seeking food for thought. These are also the types who are more likely to evangelize about and fervently hail their object of passion.

Interestingly, when passion remains in the private domain, differences in personality characteristics cannot explain why consumers develop such strong feelings for an object. Using lingerie as an example, there seems to be no relationship between a woman's personality and her passion for the product. Consumers are passionate about brands that help them transform, make them feel like a different person and allow them to live out other aspects of themselves. However, there are many different reasons why consumer passion develops.

\section{Why are consumers so passionate?}

> Passion brands express who we are /// Objects often hold special meanings and serve different functions. They help clarify who we are - to ourselves and with respect to others. They communicate social status and class, they reflect personal style, and they help to express one's identity. Attempts to explain why individuals feel such strong urges to possess and interact with their favorite objects usually focus on selfperception and personal identity projects in the lives of consumers. When consumers develop strong passionate feelings toward brands and objects, it can lead them to see those 


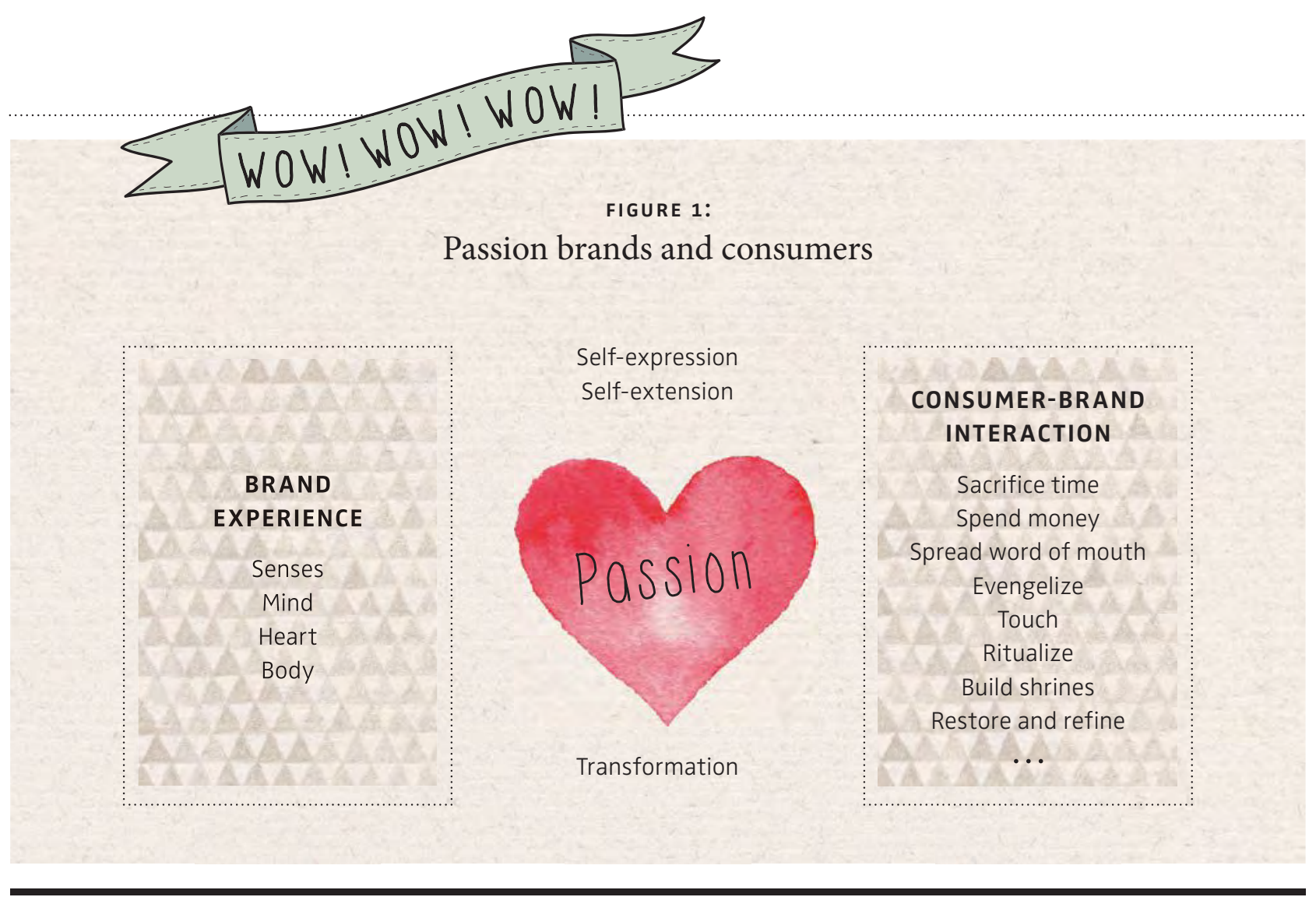

objects as sacred, thereby fulfilling spiritual needs. Just like with religiousness, a need for spirituality draws attention to the sacred object's function as a way of defining one's identity, as a source of personal development, and as a means of communicating this identity to others.

> Passion brands extend our personalities /// Passionate feelings can grow so strong that products and brands literally become extensions of the consumer. Passion is the underlying motive behind why people never leave home without their iPhone, why they carefully put back their favorite watch in its satin-lined box at night; why they play computer games until midnight; and why they never get tired of looking at their collection of Mickey Mouse figurines.

$>$ Passion brands transform consumers /// Objects we are passionate about sometimes help symbolically demarcate the boundary between self and identities that we reject. In other instances, adored objects support an identity that combines potentially conflicting aspects of one's self, such as conflicts between what a consumer wants to be and ideas that are advocated by socializing agents. Often, this means that consumers need to make major compromises a scenario in which a brand is occasionally able to help by creating a synthesis of two role identities. When brands really help us to cope with the multiple role demands in our lives, we are very prone to become passionate brand believers. Manolo Blahnik shoes and Chanel dresses, which magically transform us into stunning queens, an iPad that makes a graduate student look very cool, or Audi cars that make young professionals feel like successful entrepreneurs - they all exhibit transformative qualities, the ingredients of brand passion. However, brands do not just transform us like magic; they speak to our senses, to our minds, to our hearts, and they involve us in activities. Or in theoretical terms: They enable magical sensory, intellectual, emotional and behavioral brand experiences. 
)>

Real passion

comes with consumers being magically transformed through

extraordinary, "once in a lifetime"

brand experiences.

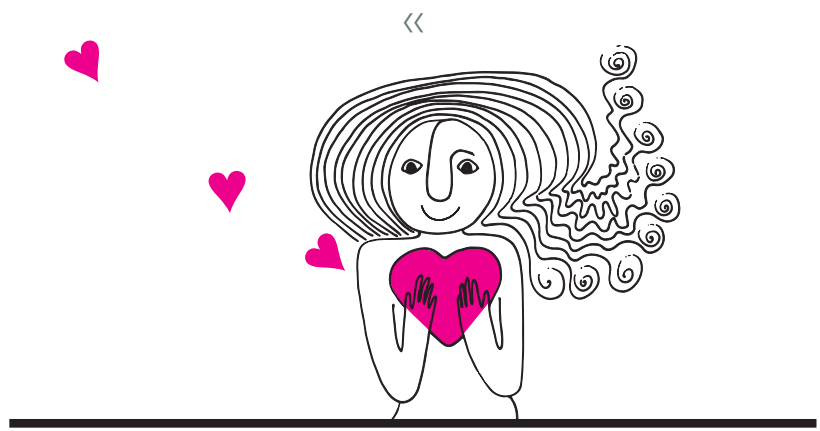

Passion for brands and what comes with it /// Research shows that there are many ways in which consumers express and act out their passionate feelings. More active and obvious deeds motivated by the consumers' strong emotionality are emblematic for passion. Passionate consumers speak of "labors of love," which require considerable investments in terms of time and money, but are deliberately and willingly done, accepting that "pleasure can be bought, but love is made".

> Passionate consumers sacrifice considerable amounts of time and money for their favorite objects. In the case of Golf GTI enthusiasts, there are fans who work no less than 40 hours per week on and for their cars in their free time. No wonder they also regularly flock to the Golf GTI Brandfest - an act quite common to brand lovers.

> Passionate consumers with a high degree of emotional attachment spread positive word of mouth. They are likely to act as missionaries trying to persuade and convince others of their object of devotion, which is commonly referred to as evangelizing. Exemplary cases can be found in work on cult followers of the Apple brand, where the authors also confirm that Mac believers engage in proselytizing and converting nonbelievers.
$>$ Looking into consumers' private domains uncovers even more interesting activities that consumers engage in, which have astounding consequences for brand management. Passion is expressed mainly in the form of frequent consumer-brand interaction, consumption rituals and brand pledges. These interactions sustain the relationship with the brand and encompass a long list of behaviors. Consumers sometimes show their feelings for objects in very subtle ways, for instance through physical closeness to their favorite object. An act such as leaning against the object or touching it, for example, is expressive of the consumer's perceived degree of attachment to the object. Passionate consumers perceive brand objects as relevant "other" subjects, which need to be cared for, exhibiting private patterns of behavior that have been commonly overlooked. Ritualistic behavior, for instance the grooming rituals of passionate car owners, integrates passionate behavior into the everyday life of consumers, thus making it more sustainable. Consumers build beautiful shrines for their collectibles, talk to the brand, pay it compliments, set up a Facebook page for it, renovate it, and carefully pass it on to their heirs. Careful restoration of the object ensures its ongoing existence, and is often time-intensive proof of the consumers' love, concern and care.

Consumer passion goes beyond ordinary feelings of desire, emotion or product attachment. Passionate consumers are not just brain-dead fanatics and bragging evangelists. They engage in respectful and caring relationships with objects and their manufacturers in an attempt to compensate for their largely disenchanted, mundane and selfcentered lives.

\section{Implications for managing passion brands}

$>$ Work on transforming qualities of the brand /// Numerous studies show that passion brands transform consumers. Brands can leverage these transforming qualities. For one thing, they should adapt to open-minded and extroverted consumer personalities. They also need to clearly help consumers in supporting qualities that the consumer does not (yet) have. This is hardly a trivial practice, as those qualities need to be imbued with strong symbolic qualities, in order to be able to trigger consumer fantasies, feelings and fun. Myths and rituals help consumers to think in other variants of themselves. Managers may want to 
think in terms of childhood fantasies, which once led us to try out many different possible roles as heroes with a sleek sports car, a sage with precious old books, or Cinderella with perfectly fitting high heels. Research refers to this phenomenon as the alternative self - the person I could have become.

$>$ Address desired lifestyles /// Brands may want to address typical lifestyles of people consumers are dreaming of and "build" these qualities into their brands. Luxury brands are role models for this strategy, and Audi shows us how it's done. In order to address the target group of modern mainstream consumers, the car is depicted within the social environment of the postmodern success-oriented societal class.

> Support consumers' interactions with the brand /// Because passionate consumers also like to take on a caring role, work with their brands, maintain them and dedicate time, space and money to them, companies can support their customers in these efforts. Shoes, for example, could come with a dedicated shoe-shining kit, crystal figurines with displays, bikes could be supplemented with replacement parts, or lingerie with a lingerie storage set. Dedicated consumers also go out of their way to make pilgrimages to brands' birthplaces. Experiential places, such as brand worlds (Crystal World by Swarovski), museums (the Porsche museum or BMW World), and flagship stores (the Chanel flagship store in Tokyo) cater to the needs of passionate consumers.

$>$ Re-enchant your brand with magic /// Real passion, however, comes with consumers being magically transformed through extraordinary, "once in a lifetime" brand experiences. It's the little magic moments when we unwrap and place our new little figurine in the glass display, the grand event of seeing them illuminated in the brand palace at their birthplace or the many other experiences that spark brand passion among consumers.

I.

\section{FURTHER READING}

\section{Hemetsberger, Andrea, Melanie Hoppe, Kurt Matzler, Caroline Mühlbacher and Elisabeth A. Pichler (2010):}

"Sensing and Experiencing the Transformative Power of Private Brands - An Investigation into

Passionate Consumption of Lingerie",

Proceedings of the $39^{\text {th }}$ EMAC conference, Copenhagen, CD-ROM.

Hoppe, Melanie, Andrea Hemetsberger, Elisabeth A. Pichler and Kurt Matzler (2009):

"The Transformative Power of Brands An Investigation into the Relationship between Self-transformation and Consumer Passion", Proceedings of the $38^{\text {th }}$ EMAC conference, Nantes, CD-ROM.

Pichler, Elisabeth A. and Andrea Hemetsberger (2008):

"Driven by Devotion - How Consumers Interact with Their Objects of Devotion", in A. Y. Lee and D. Soman (eds.), Advances in Consumer Research, Vol. 35, pp. $439-443$.

Pichler, Elisabeth A. and Andrea Hemetsberger (2007):

"Hopelessly Devoted to You: Towards an Extended Conceptualization of Consumer Devotion", in G. Fitzsimons and V. Morwitz (eds.), Advances in Consumer Research, Vol. 34, pp. $194-199$. 